\title{
International Regulation of "Lethal Autonomous Weapons Systems" (LAWS): Paradigms of Policy Debate in Japan
}

\author{
Daisuke Akimoto
}

\begin{abstract}
Civil society organizations have warned that if "lethal autonomous weapons systems" (LAWS) are created, such weapons would cause serious problems with regards to human rights. Although "fully autonomous" weapons do not exist at this stage, several countries are thought to have developed "semi-autonomous" weapons equipped with artificial intelligence. LAWS related issues have been a part of international discussions in the United Nations, and the Japanese government has actively participated in these conferences. Japanese politicians have also discussed issues related to LAWS in the National Diet since 2015. This article provides multiple paradigms of Japan's policy toward LAWS from the perspectives of international relations theory, and attempts to explore possible solutions to the international regulation of LAWS in international law.
\end{abstract}

Keywords AI, AI weapons, killer robot, LAWS (lethal autonomous weapons systems), meaningful human control

\section{Introduction}

The international community has been warned by civil society of future scenarios in which human beings may be targeted and killed by "autonomous weapons systems" or "killer robots" which are reminiscent of the popular film The Terminator (Kowalska 2018). On November 19, 2012, Human Rights Watch and International Human Rights Clinic (IHRC) of Harvard Law School published a report encouraging the ban of killer robots, defined as "fully autonomous weapons that could select and engage targets without human intervention" (Human Rights Watch and International Human Rights Clinic Human Rights Program at Harvard Law School 2012, 1). The fifty-page long report is one of the first publications addressing the legal prohibition of killer robots by a nongovernmental organization (NGO) that warns of the potential danger of killer 
robots in light of human rights and international law (Human Rights Watch 2012). The "Campaign to Stop Killer Robots" (2013) as a group of NGOs sparked international debate on the legal and ethical questions regarding the development of killer robots, or "lethal autonomous weapons systems" (LAWS). Although the scope of LAWS or killer robots has not been clearly defined as of yet, they have been referred to as "weapons that can select, detect, and engage targets with little to no human intervention" (Evans and Salmanowitz 2019).

In 2013, the United Nations (UN) decided to discuss concerns about LAWS within the framework of the "Convention on Certain Conventional Weapons" (CCW), which prohibits or restricts the use of specific weapons that "may be deemed to be excessively injurious or to have indiscriminate effects" (UNOG 2019a). The CCW was signed in 1980 in Geneva and entered into effect in 1983. International discussions regarding legal prohibition of LAWS at the CCW began in 2014. Meanwhile, over 1,000 leading researchers and business leaders, such as Stephen Hawking, Elon Musk, and Steve Wozniak, signed an open letter calling for a ban on killer robots as fully autonomous weapons on July 27, 2015 (Zakrzewski 2015). On August 21, 2017, Elon Musk led a group of 116 specialists on artificial intelligence (AI) in submitting a letter requesting a ban on killer robots to the UN. They argued that the creation of killer robots should be legally banned because such technology would bring about the third revolution in warfare, followed by the invention of the gun and nuclear weapons (Guardian 2017).

Parties at the discussions on the CCW can be divided into those supporting early regulation or prohibition of LAWS and those against such measures. In particular, the United States, Russia, and China have shown reluctance in supporting the legal prohibition of the development of LAWS because they fear that such a regulation could be disadvantageous for their military strategy. Indeed, it has been considered that the United States, China, Israel, Russia, South Korea, and the United Kingdom have already developed "semi-autonomous" weapons systems as "precursors" of fully autonomous weapons systems (Japan Today 2014).

Japan has supported the CCW framework and the annexed Protocols (MOFA 2018a, 239-40). Internationally, the Japanese government has dispatched delegations to a variety of international discussions on the LAWS issues. Domestically, Japanese politicians have been asking questions concerning LAWS at the National Diet of Japan, the Japanese parliament, since 2015; but, the Japanese government has been unwilling to create a legally binding treaty to ban LAWS at this stage because the government is concerned about whether such a regulation would have the potential to hinder development of Japan's AI technology for national defense.

Four research questions regarding Japan's policy on LAWS are raised here. First, what are the reasons for Japanese politicians to support legal prohibition of 
LAWS with regard to Japan's postwar normative factors? Second, to what extent did the Japanese government make diplomatic commitments to the international regulation of LAWS from a neoliberalist perspective? Third, outside these diplomatic commitments, were there any domestic and realist factors which influenced Japan's decision not to support a legally binding treaty to ban LAWS? Fourth, how have international and structural factors influenced Japan's policy on LAWS? The purpose of this article is to provide answers to these research questions and multilayered perspectives surrounding Japan's policy toward the legal regulation of LAWS. By applying "analytical eclecticism," combined with theoretical aspects of orthodox international relations theory (classical liberalism, neoliberalism, classical realism, and neorealism), this article seeks to elucidate multiple factors behind Japan's policy toward LAWS regulation and to explore possible pathways toward international regulation of LAWS.

\section{Literature Review: Pros and Cons on the Development of AI Weapons}

The notion of "autonomous weapons" is not necessarily a new one. For instance, "landmines" are able to select and engage their own targets causing lethal consequences (Robillard 2018). Likewise, Germany developed and utilized autonomous acoustic torpedoes during the Second World War (Advisory Council on International Affairs 2015,8). Still, the development of AI technology for military use has brought about concern regarding its potential mutations for warfare. The issue of robotics and AI technology was examined by Ray Kurzweil, who argues that the ability of AI would surpass that of human beings (Kurzweil 2005). Noel Sharkey (2007) warns that "robot wars are a reality" and suggested creating "international legislation and a code of ethics for autonomous robots at war before it is too late." One of the first academic publications addressing issues with LAWS was authored by Peter W. Singer. In the book Wired for War: The Robotics Revolution and Conflict in the 21st Century, Singer (2009) cautions that autonomous weapons may drastically change the nature of armed conflict.

In an official report submitted to the United Nations General Assembly (UNGA) on August 23, 2010, Philip Alston (2010) points out the issue of unmanned or robotic systems, in light of international humanitarian law. A report by the Human Rights Watch and the International Human Rights Clinic Human Rights Program at Harvard Law School (2012), "Losing Humanity: The Case Against Killer Robots," provides critical analysis on killer robots in the context of human rights. On November 21, 2012, the United States Department of Defense (USDOD) officially announced its policy on the development and use of autonomous weapons systems, expressing that the Department of Defense (DOD) was not projected to develop "fully autonomous" AI weapons, which would be capable of conducting military operations without human control (USDOD 
2012), but that the DOD had already developed "semi-autonomous" weapons. In an official report submitted to the Human Rights Council of the UNGA on April 9, 2013, Christof Heyns (2013) suggests that states should establish "national moratoria" on "lethal autonomous robotics" (LARs) through the jurisdiction of international humanitarian and human rights law.

Di Nucci and Santoni de Sio (2016) address issues relating to drones as "remotely controlled weapons" from legal, philosophical, and socio-technical perspectives. Armin Krishnan (2009) examines the technological opportunities and legal and ethical problems of autonomous robots in terms of international law. Alex Leveringhaus (2016) also investigates both the negative and positive aspects of autonomous weapons, particularly the question of legal responsibility in automated warfare. Likewise, Jha (2016) analyzes the moral, ethical, and legal issues of killer robots. Additionally, Ingvild Bode and Hendrik Huelss (2018) shed light on changing "norms" regarding the international regulation of autonomous weapons from a constructivist perspective.

In contrast, Michael N. Schmitt and Jeffrey S. Thurnher (2013) oppose the campaign to ban autonomous weapons, arguing that the application of the law of armed conflict could regulate the development and use of autonomous weapon systems. Likewise, Kenneth Anderson and Matthew Waxman (2013) argue that not prohibition but the regulation of development and use of autonomous weapon systems is appropriate for international law. Anderson, Reisner, and Waxman (2014, 395-98) reinforce this argument and criticize the campaign to ban LAWS, calling them "misguided calls." Moreover, Vincent C. Müller (2016) explicitly opposed the legal prohibition of the development and use of LAWS, arguing that LAWS would reduce human suffering in armed conflicts and would not pose a threat to humanity.

One of the most difficult problems in the study of LAWS is the definition (Crootof 2015), since LAWS do not exist yet. Human Rights Watch classified autonomous weapons systems into three types: (1) "human-in-the-loop weapons (robots that can select targets and deliver force only with a human command);" (2) "human-on-the-loop weapons (robots that can select targets and deliver force under the oversight of a human operator who can override the robots' actions);" and (3) "human-out-of-the-loop weapons (robots that are capable of selecting targets and delivering force without any human input or interaction)." The second and third types are categorized as "killer robots" that need to be legally banned before they are developed and deployed to battlefields (Human Rights Watch and International Human Rights Clinic Human Rights Program at Harvard Law School 2012, 2-3). LAWS as "fully autonomous weapons" should be categorized as the third type.

Meanwhile, previous scholarly works on Japan's policy on LAWS are limited, and even less attention has been paid to theoretical explanations of the issue. This research gap stems from the fact that the LAWS issue is a relatively new research 
field in Japan. Notably, all legislators of both ruling and opposition parties showed their opposition to the creation of LAWS because they believe that LAWS may violate international humanitarian law and might occasion tremendous human rights violations. The Japanese government, however, has been reluctant to ban LAWS by creating a legally binding treaty, arguing that it was premature to jump to such a conclusion. But why is the government ambivalent to LAWS issues? In an attempt to provide multiple explanations of Japan's policy toward LAWS, theoretical viewpoints supplied by international relations are applied in the following sections.

Aimed at investigating multiple theoretical factors for Japan's policy on lawful prohibition of LAWS, this article employs "analytical eclecticism" as a research method, combined with orthodox realist and liberalist theories of international relations. In the field of Japanese politics and international relations, analytical eclecticism was originally proposed by Peter Katzenstein $(2008,3)$, who observed that: "Some writings on Japanese security may, in the future, be able to take a more eclectic turn, by incorporating elements drawn from three different styles of analysis-the testing of alternative explanations, the rendering of synthetic accounts, and historically informed narratives." By applying analytical eclecticism, this article attempts to examine Japan's policy on LAWS from four theoretical perspectives-classical liberalism, neoliberalism, classical realism, and neorealism. Since observers of international relations and Japanese politics tend to take on either a particular or a number of theoretical stances, this research aims to contribute to providing an original analysis with multilayered theoretical explanations of Japan's policy on LAWS.

\section{Classical Liberalism: The Political Debate on the Prohibition of LAWS in Japan}

From the perspective of classical liberalism or idealism based on the premise that the "application of reason and ethics to international relations" can lead to international peace (Kegley and Blanton 2011, 37-38), it is understandable for Japanese politicians to support the legal prohibition of LAWS. From a classical liberalist viewpoint, it is fair to argue that there has existed "antiwar pacifism" and a culture of "antimilitarism" in Japan triggered by the devastation of the Asia Pacific War, especially the atomic bombing of Hiroshima and Nagasaki (Berger 1993, 1998). In addition, Article 9 of the Japanese Constitution, which stipulates renunciation of war and non-possession of war capabilities (NDL 1946), has impacted Japan's security policy and Japan's attitude toward militarism. Since 2015, legal regulation or a complete ban on killer robots has been discussed in the Japanese National Diet by some legislators who oppose the creation of LAWS from ethical and legal viewpoints. 
On April 14, 2015, Kazuyuki Hamada of the Party for Future Generations (Jisedainoto) raised the issue of LAWS for the first time as a member of the Diet. He asked the question of how the Japanese government should address this issue during an informal meeting of experts on LAWS in Geneva, held April 1317, 2015. State Minister for Foreign Affairs Minoru Kiuchi explained that "it is important to reach an international understanding with other countries on LAWS through the exchange of opinions among experts" (NDL 2015). Hamada then asked how the Ministry of Defense (MOD) should respond to the regulation of LAWS. In response, Defense Minister Gen Nakatani explained that the MOD would continue to research the application of an "unmanned system" to the SelfDefense Forces (SDF), so that the SDF could reduce the burden of "surveillance" as well as the disposal of "explosive substances" (ibid.).

On December 1, 2017, Seiichi Kushida of the Japan Innovation Party (Nihon Ishinnokai) raised the issue of LAWS in the Committee on Education, Culture, Sports, Science, and Technology of the Lower House. In response, Yoshimasa Hayashi, as Minister for Education, Culture, Sports, Science and Technology (MEXT), stated that the Japanese government supports the international regulation of AI technology for military use (NDL 2017a). On December 5, 2017, Kuniko Inoguchi of the Liberal Democratic Party (LDP), formerly a professor of international politics at Sofia University and former Ambassador Extraordinary Plenipotentiary to the Conference on Disarmament, raised concerns about LAWS and requested that the Japanese government support international negotiations on the legal regulation of LAWS within the framework of the CCW. In response, State Minister for Foreign Affairs Masahisa Sato stated that the Japanese government recognized the possible impact of LAWS on security issues, and assured the public that Japan has no intention of developing "fully autonomous weapons." Notably, Inoguchi suggested that LAWS should be legally prohibited by the creation of "Protocol 6 of the CCW" (NDL 2017b).

On February 14, 2018, Kiyohiko Toyama of Komeito asked Defense Minister Itsunori Onodera whether the Japanese government had plans to develop LAWS. Onodera replied that although there was no consensus on the definition of LAWS, the "MOD had no plans to develop" such weapons. At the same time, Onodera emphasized that the Defense Ministry would seek to research and develop the application of AI technology on Japan's defense equipment, "for the purpose of securing safety and mitigating the burden on [SDF] staff" (NDL 2018a). Likewise, Foreign Minister Taro Kono confirmed that the Foreign Ministry would be actively involved in the international discussion concerning the legal regulation of LAWS within the framework of the CCW (ibid.).

On March 9, 2018, Kiyohiko Toyama raised the issue of LAWS in the Committee on Foreign Affairs in the Lower House. He pointed out that China seeks to improve its research and development of AI weapons systems, and that South Korea had already deployed an AI-equipped machine gun, SGR-A1, to the 
Korean Demilitarized Zone. In response to Toyama's remark, Foreign Minister Kono assured the Committee that the Japanese government would not create "completely autonomous weapons that are out of human control" (NDL 2018b). Additionally, Parliamentary Vice-Minister of Defense Tatsuo Fukuda stated that though there is no clear definition of LAWS or semi-LAWS, the Japanese government would not develop weapons systems "which are prohibited by domestic and international laws." Toyama then emphasized that LAWS could lead to a third revolution in warfare, and therefore, LAWS should be legally regulated before it is ever completed (ibid.).

On April 18, 2018, Shinji Oguma of the Party of Hope (Kibonoto) touched on the issue of LAWS in relation to the Safe Schools Declaration. Oguma argued that unlike human beings who can avoid attacking schools in wartime, killer robots might not be able to follow the guidelines of the declaration (NDL 2018c). On November 14, 2018, Kiyohiko Toyama raised the LAWS issue in the Committee on Foreign Affairs in the Lower House again. Toyama asked for Japan's response to the second meeting of experts on LAWS, within the framework of the CCW, held in August 2018. Foreign Minister Taro Kono replied that the "Japanese government would like to positively and constructively participate in the international discussion" on the legal status of LAWS "in order to agree on a shared understanding" of the LAWS issue (NDL 2018d).

On January 28, 2019, Foreign Minister Kono expressed his concern about LAWS in the Diet, stating "just as gunpowder and nuclear weapons changed the way wars were conducted in the past, artificial intelligence could fundamentally alter the course of future wars" (Asahi Shimbun 2019). On March 11, 2019, a project team of Komeito presented a proposal for Japan to take a leadership role in the international regulation of LAWS to Foreign Minister Kono. Notably, Komeito requested that the foreign minister facilitate international agreement on the regulation of LAWS, such as a "political declaration" or a "code of conduct" within the framework of the CCW (Japan Times 2019). Furthermore, Kaneshige Wakamatsu of Komeito in the House of Councillors on April 4, 2019 argued that Japan should proactively contribute to the international regulation of LAWS because Japan is the sole state that has suffered from nuclear weapons (NDL 2019). Significantly, Wakamatsu's argument for regulating LAWS is consistent with antiwar/antinuclear pacifism as well as classical liberalism.

As shown in the proceedings of the National Diet, the Japanese legislators of both ruling and opposition parties expressed their support for the legal prohibition or regulation of LAWS on ethical and legal grounds. Their opposition to the creation of LAWS is congruous with Japan's antiwar pacifism and antimilitarist culture, as a philosophical component of classical liberalism. 


\section{Neoliberalism: Japan and the International Debate on the Prohibition of LAWS}

From the perspective of neoliberalism, which rests upon the premise that "international cooperation" is possible and desirable in international relations by establishing "international regimes" or international legal frameworks (Kegley and Blanton 2011, 42-43), it is natural and ideal for Japan to participate in international discussions concerning the legal regulation of LAWS. In light of neoliberalism, Japan's contribution to "international cooperation," based on the Preamble of the Japanese Constitution, can be regarded as liberal internationalism (O'Hanlon 2007). In fact, the Preamble of the Japanese Constitution emphasizes the importance of Japan's responsibility to international cooperation (NDL 1946). The international movement to restrict LAWS, especially the Campaign to Stop Killer Robots, has been active since 2012 and the UN is discussing the international regulation of LAWS as an issue of arms control and disarmament, to which the Japanese government has made a continuous commitment.

At a CCW conference in November 2013, it was decided that LAWS related issues should be discussed. In May 2014, Japanese Ambassador to the Conference on Disarmament Toshio Sano, officials of Ministry of Foreign Affairs (MOFA), MOD, and Ministry of Economy, Trade and Industry (METI), as well as Professor Heigo Sato of Takushoku University, as an expert on arms control and disarmament, attended the CCW to discuss LAWS (Delegation of Japan to the Conference on Disarmament 2019).

In the CCW conference held in Geneva on May 13, 2014, Japanese Ambassador Toshio Sano explained Japan's stance on LAWS and expressed deep appreciation for the role of civil society in contributing to awareness of humanitarian concerns related to the development of LAWS. Sano stressed that the Japanese government was taking an interest in the LAWS issue and would like to engage in international discussions. He also stated that Japan would continue to research and develop "non-lethal autonomous technology for defense purposes" but that the government would not develop "fully autonomous" weapons systems (Delegation of Japan to the Conference on Disarmament 2014a).

In the CCW conference on November 13, 2014 which took place in Geneva, Ambassador Sano explained Japan's stance on LAWS in a speech. Sano commended the French Ambassador at the informal meeting of experts on LAWS in May 2014, calling his leadership "fruitful and insightful," and expressed Japan's support for further discussions on LAWS within the framework of the CCW (Delegation of Japan to the Conference on Disarmament 2014b).

The second informal meeting of experts on LAWS in the CCW was held in Geneva on April 13, 2015. The Japanese government expressed its support for the meeting to facilitate a discussion of the core concepts regarding LAWS, such as its definition, the implications of autonomy, and "meaningful human control." 
Furthermore, the government stated that Japan had no plan to develop "fully autonomous" weapons systems (UNOG 2015).

On October 26, 2015 in New York, Ambassador Sano delivered a speech at the first committee of the Seventieth Session of the UNGA. Sano stated that Japan commended the "leadership of Germany in the second informal meeting of experts" and that Japan would support further discussion, particularly on the definition of LAWS, for the Fifth CCW Review Conference in 2016 (MOFA 2015). On November 12, 2015, Sano made a speech at the CCW conference in Geneva and expressed Japan's view that "it is most important to identify broader common ground for our understanding" such as the definition of LAWS and the concept of meaningful human control (Delegation of Japan to the Conference on Disarmament 2015). The third CCW meeting of experts on LAWS chaired by German Ambassador Michael Biontino was held in Geneva on April 11, 2016. In the meeting, the Japanese government submitted its working paper on LAWS and stressed the importance of the meeting (UNOG 2016).

On November 13, 2017, the first meeting of the "Group of Governmental Experts" (GGE) on LAWS as a subsidiary body of the CCW was held in Geneva. The mandate of the GGE is decided based on the High Contracting Parties to the CCW, and the experts widely discussed issues related to LAWS from legal, ethical, military, and technological perspectives (UNODA 2017; UNOG 2019b). The 2017 CCW conference was held in Geneva on November 20, 2017. Ambassador Nobushige Takamizawa and officials of MOFA and MOD attended the meeting to discuss the arguments expressed in the first GGE session (MOFA 2017). Ambassador Takamizawa, MOFA and MOD officials, and Professor Heigo Sato participated in the second GGE meeting on April 9, 2018 (MOFA 2018b). The Japanese Ambassador and officials of the MOFA and the MOD attended the third GGE meeting on August 27, 2018, where they argued that the Japanese government would not develop LAWS and that "meaningful human control" over weapons should be required (MOFA 2018c).

On November 19, 2018, Ambassador Takamizawa and Japanese foreign and defense officials attended the CCW conference to discuss concerns about LAWS in Geneva (MOFA 2018d). On March 25-29, 2019, the GGE on LAWS was held within the framework of the CCW in Geneva. The Japanese government submitted a working paper to the GGE on March 21, 2019, in which the government requested the GGE facilitate a "direction towards possible future actions of the international community on LAWS," in order to reach a "mutual understanding" on the definition of LAWS and meaningful human control as well as a consensus on an "outcome document" (MOFA 2019, 2).

Thus, the Japanese government has actively participated in international discussions to regulate LAWS in the framework of the CCW, demonstrating its international cooperation. At the same time, the Japanese government has been consistent about the need for "meaningful human control" as a key norm for 
regulating the use of AI powered weapons. Japan's support for the international regulation of LAWS in the CCW framework has been coherent and it can be regarded as international cooperation on the theoretical premise of neoliberalism.

\section{Classical Realism: Japan's National Interests and the Development of AI Weapons}

According to classical realism in international relations theory, it is logical for sovereign states to pursue their national interests and increase economic and military power for independence and survival (Kegley and Blanton 2011, 3132; Morgenthau 2006). This is how the Japanese government has developed and "normalized" its defense capabilities (Hook 1996; Oros 2008). In this sense, the classical realist perspective explains why the Japanese government has been reluctant to support the legal prohibition of LAWS, despite its active participation in the CCW. Japan's reluctance to enact a legal ban on LAWS is related to its national interests, particularly in the application of AI technology to the defense capabilities. As observed by Heigo Sato $(2017,59)$, in terms of national interests, it is politically and militarily disadvantageous for states to prohibit the development of military technology, because the military necessity might arise in the future. The same is true for the international regulation or prohibition of "fully autonomous" weapons systems which as of yet do not exist.

For example, Japanese Ambassador Sano made a speech at the CCW conference held on May 13, 2014 and stressed the importance of the "peaceful use" of autonomous technology by providing an example of the deployment of robots for search, rescue, and surveillance after the Fukushima Daiichi nuclear power plant disaster (Delegation of Japan to the Conference on Disarmament 2014a). Although the Japanese government promised that Japan would not develop "robots with humans out of the loop," the government also emphasized the significance of the "dual-use" nature of robotic technologies and argued that it is not easy to draw a line between civil use and military use (UNOG 2015).

At the 2016 CCW conference, the Japanese government expressed its concern that "technologies of autonomous systems usable for LAWS have a high affinity with those technologies that have been under research and development in civil use" (UNOG 2016). The government also argued that it is critical to "ensure the promotion, research, and development of the peaceful and sound use of robots by drawing on the expertise and experiences gained in other regimes dealing with dual-use technologies" (ibid.).

Notably, former Defense Minister Satoshi Morimoto argued that Japan should develop AI-equipped defense capabilities given the decreasing population of Japan. Morimoto explained that AI-equipped defense capabilities are important to the defense of Japan because the Japanese Self-Defense Forces 
would be able to conduct military operations with less fear of death in the event of contingencies (NHK 2018a). Moreover, the Ministry of Foreign Affairs of Japan expressed a cautious attitude toward the legal prohibition of LAWS because such an international legal framework might jeopardize Japan's international competitiveness in the development of AI technology and robotics (Reuters 2018).

The Japanese government argued that it was premature to create some international regulation on autonomous weapons because comprehensive understandings of the issue had not been discussed at the CCW. In particular, Ambassador Takamizawa pointed out that the potential for civil use of AI technology should be taken into consideration when discussing related LAWS issues (NHK 2018b). The Japanese government made a cabinet decision regarding the National Defense Program Guidelines (NDPG) on December 18, 2018. The NDPG noted that the Japanese government would invest in AI-related defense equipment and that this could be a game changer in strategic environments. By analyzing the NDPG, Sankei Shimbun (2018) reported that Japan should not regard military use of AI technology as taboo, otherwise the development of military technology for national defense would be jeopardized. In fact, the Japanese government plans to "research and develop AI or unmanned equipment to secure safety and reduce the burden of the Self-Defense Forces" (Asahi Shimbun 2019). More specifically, it has been reported that Japan has developed "military drones" in cooperation with the United States and Israel (Prakash 2017). In other words, the Japanese government has no active plans to create "fully autonomous" weapons systems, but has developed "semi-autonomous" defense capabilities.

Hence, from a classical realist viewpoint, the Japanese government has been cautious about creating a legally binding treaty to ban LAWS due to its national interests in the dual use nature of AI technology as well as the strategic importance of AI-equipped defense capabilities such as "semi-autonomous" defense systems. Moreover, as the joint development of "military drones" between Japan and the United States and Israel indicates, Japan's policy on the development of AI weapons seems to be under the influence of the U.S. military strategy and structural and international factors as examined in the following section.

\section{Neorealism: The Development and Deployment of AI Weapons in the World}

According to neorealism, international relations is anarchic in cases where balance of power is important or a hegemonic state influences the policymaking of other countries (Kegley and Blanton 2011, 35, 66). From a neorealist perspec- 
tive, Japan's security policy has been shaped in response to the changing international security environment (Pyle 2007; Oros 2017). In this regard, it is theoretically fair to consider that Japan's policy toward LAWS has been influenced by U.S. policy on autonomous weapons in an anarchic world. Indeed, Japan has invested in the development of AI-equipped defense capabilities in response to the rise of Chinese military power and changing U.S. military strategy (Prakash 2017).

The USDOD announced its policy on autonomous weapons systems in Directive 3000.09 on November 21, 2012, stipulating that the United States would not develop "fully autonomous" weapons systems. However, the USDOD document also noted that the United States would utilize "human-supervised" autonomous weapons systems, semi-autonomous weapons systems, and "nonlethal" autonomous weapons systems (USDOD 2012, 3). In other words, the United States will develop AI-equipped weapons as long as they are not "fully autonomous" weapons systems which are completely out of human control.

The application of artificial intelligence to the automation of military technology has been pursued by both the Barack Obama and Donald Trump administrations. On November 15, 2015, the USDOD announced its so-called "third offset strategy" in response to the military modernization of China and Russia. The offset strategy of the United States is an "approach to military competition that seeks to asymmetrically compensate for a disadvantaged position" (NIDS 2017, 212). The third offset strategy is based on the advancement of AI and autonomy for military technology and operations (ibid., 213). In particular, the USDOD has tried to introduce "autonomous deep learning systems" into the military capabilities and developed "semi-autonomous" weapons, such as "unmanned underwater vehicles" (UUVs) (ibid., 214) and "unmanned aerial vehicles" (UAVs) that can autonomously decide to attack enemy aircraft (Leys 2018, 52).

According to the National Security Strategy announced by President Donald Trump in December 2017, the U.S. government has plans to lead in research, technology, invention, and innovation, especially in the field of artificial intelligence from "self-driving cars" to "autonomous weapons" (White House 2017, 20). For instance, it was reported that Google had made a contract with the USDOD to support a pilot project by applying its AI solutions to "drone targeting" (Fang 2018). The U.S. government, therefore, has clearly pursued supremacy in the field of AI or machine intelligence (MI) as a military strategy in response to the changing security environment. The Center for Strategic and International Studies (CSIS) argued that "MI will redefine the balance of both economic and military power around the world" (Carter, Kinnucan, and Elliot 2018, 16). Russian President Vladimir Putin stated in September 2017 that "whoever becomes the leader in [MI] will become the ruler of the world," and China's New Generation of Artificial Intelligence Development Plan in 2017 
Table 1. "Semi-Autonomous" Weapons Systems in Development or Operation

\begin{tabular}{l|l|l}
\hline \hline & \multicolumn{1}{|c|}{ Human in the Loop Weapons } & \multicolumn{1}{c}{ Human on the Loop Weapons } \\
\hline Land & $\begin{array}{l}\text { Guardium and Border Protector (Israel) } \\
\text { SGR-1 (South Korea) }\end{array}$ & $\begin{array}{l}\text { Iron Dome (Israel) } \\
\text { C-RAM, Patriot and THAAD (United States) }\end{array}$ \\
\hline Sea & $\begin{array}{l}\text { Protector USV (Israel) } \\
\text { Sea Hunter (United States) }\end{array}$ & $\begin{array}{l}\text { Aegis and CIWS Phalanx (United States) } \\
\text { Goalkeeper (Netherlands) } \\
\text { PMK-2 (Russia) }\end{array}$ \\
\hline Air & $\begin{array}{l}\text { MQ-1 Predator (United States) } \\
\text { MQ-9 Reaper (United States) }\end{array}$ & Harpy, Harop (Israel) \\
\hline
\end{tabular}

Source: Compiled from Bode and Huelss (2018, 402); Iwamoto (2018, 290).

stressed that "machine intelligence [is] the strategic technology that will lead in the future" (ibid.). Chinese President Xi Jinping "explicitly called for a greater national focus on military AI research" in 2017, and the Beijing Institute of Technology (BIT) recruited thirty-one talented teenagers to "train as the world's youngest AI weapons scientists" (Kilbride 2018).

In reality, the development of AI military technology can be observed around the world, as shown in Table 1, though they are presently only "semiautonomous" or "human-supervised" weapons systems. The U.S. government released a video displaying "an autonomous drone swarm of 103 individual robots" flying over California. Kalashnikov, the main "defense contractor" for the Russian government, announced that it had manufactured autonomous weapons capable of deciding on shooting targets. Israel has developed an "autonomous loitering munition" called the Harop which can "dive-bomb radar signals" without human control, and has reportedly been deployed on battlefields. South Korea also has developed a "drone swarm" (Perrigo 2018).

The development of AI powered military technology shows that it is politically and strategically important for these countries to possess autonomous weapons systems. This is a "strategic factor" explaining why the United States, Russia, and China should not support the international campaign to ban LAWS, as observed by Elke Schwarz of the International Committee for Robot Arms Control (ibid.). This can also be inferred as a structural reason for why Japan, as a key U.S. ally, has been reluctant to support the creation of a legally binding treaty to ban LAWS in an anarchic world. Japan's policy on international regulation of LAWS has been inevitably influenced by the anarchic nature of the international system, as well as its military alliance with the United States, as emphasized by neorealist theorists. 


\section{The Future of International Regulation and Prohibition of LAWS}

So far the stances of the Japanese government and Japanese Diet Members have been discussed from four theoretical perspectives. They have been supportive of the international regulation of LAWS as "fully autonomous" weapons systems, but the government has also been protective of peaceful or defensive uses of AI technology in an anarchic world, where several countries have already developed "semi-autonomous" weapons systems. Still, the question regarding the feasibility of legally regulating LAWS remains. Given the domestic and international debates on LAWS, how can the international community regulate, and perhaps even prohibit, the development and use of LAWS? There are at least three possible approaches to pre-emptively regulating or prohibiting the development of LAWS through international law.

First, as observed in this article, the CCW is a legitimate framework for regulating or prohibiting the development of LAWS. The CCW is a multilateral treaty which was created to "ban or restrict the use of specific types of weapons that are considered to cause unnecessary or unjustifiable suffering to combatants or to affect civilians indiscriminately" (UNOG 2019c). The legal components of the CCW are: Protocol 1 on "non-detectable fragments;" Protocol 2 on "prohibitions or restrictions on the use of mines, booby traps and other devices;" Protocol 3 on "prohibitions or restrictions on the use of incendiary weapons;" Protocol 4 on "blinding laser weapons;" and Protocol 5 on "explosive remnants of war" (ibid.). In the CCW framework, blinding laser weapons were pre-emptively prohibited before they were deployed on the battlefield. Likewise, the development of LAWS can, in theory, be pre-emptively outlawed by creating Protocol 6. However, a clear limitation of the CCW framework is its "rule of consensus" as a decision-making process (Acheson 2016, 1). In other words, if the United States, Russia, and other countries which have developed AI weapons intend to block the international regulation of LAWS in the CCW framework, it would be impossible for the international community to create a new protocol to ban LAWS.

Second, even if negotiations in the CCW framework result in failure, it would still be possible for either the international community or civil society to create a legally binding instrument. By creating such a treaty, not only the development and use but also the acquisition and procurement of LAWS would be prohibited. In fact, the international community and civil society have pursued the creation of a formal multilateral "treaty" banning LAWS, as with the case of the "Treaty on Prohibition of Nuclear Weapons" (TPNW) signed on July 7, 2017. The TPNW was supported by as many as 122 countries in the UNGA, and acts as a legally binding framework for prohibiting and eliminating nuclear weapons. However, nuclear-armed states have yet to sign the TPNW, and Japan has been unsupportive of the treaty in spite of its status as the sole country to have experienced nuclear attacks (Akimoto 2018). The Japanese government 
has argued that it opposes the TPNW because the treaty would widen the gap between nuclear and non-nuclear countries. Instead, the government decided to facilitate nuclear disarmament within the framework of the Treaty on the Non-proliferation of Nuclear Weapons (NPT). Still, Japan's diplomatic stance on nuclear disarmament and its opposition to the TPNW seem to be paradoxical (ibid.). As in the case of the TPNW, the Japanese government has been unsupportive of the creation of a legally binding document to ban LAWS at this stage. Also, as in the case of the TPNW, it is highly unlikely that the United States and Russia would accept a legally binding instrument banning LAWS, and, as a result, the effectiveness of the possible treaty aiming to outlaw LAWS would be limited.

Third, it is feasible for the international community to confirm the applicability of Article 36 of the "Protocol Additional to the Geneva Conventions of August 12, 1949, and relating to the Protection of Victims of International Armed Conflicts (Protocol 1)," adopted in Geneva on June 8, 1977 to AI weapons, and to agree on a "political declaration" of the outcome of the international negotiations around regulating LAWS. Article 36 of Protocol 1 of the Conventions on "new weapons" reads: "In the study, development, acquisition, or adoption of a new weapon, means, or method of warfare, a High Contracting Party is under an obligation to determine whether its employment would, in some or all circumstances, be prohibited by this Protocol or by any other rule of international law applicable to the High Contracting Party" (United Nations 1979, 21). A political declaration is not a legally binding document, but it is notable to have reached a certain consensus on international regulation and prohibition of LAWS. Of course, civil society, especially the Campaign to Stop Killer Robots, would prefer the creation of a legally binding treaty as the ultimate goal, but the political declaration can be seen as the first step toward a more exhaustive international agreement on the regulation and prohibition of LAWS. In retrospect, the "Universal Declaration of Human Rights," adopted by the UNGA on December 10, 1948, was not legally binding in the strictest definition, but the declaration was eventually upgraded to the "International Covenant on Civil and Political Rights" adopted by the UNGA on December 19, 1966 (United Nations 1976). Therefore, it is still possible for the international community and civil society to upgrade the political declaration to ban LAWS into a legally binding treaty. This is one of the possible outcomes of this first step toward the pre-emptive illegalization of LAWS.

\section{Conclusion}

This article has examined Japan's policy toward the international discussion surrounding the legal regulation of LAWS by applying theoretical perspectives of international relations. First, the classical liberalist perspective shows that Japanese Diet members support the international discussion to ban LAWS 
for moral and ethical reasons. Most importantly, it was revealed that there exists bipartisan support for legal prohibition of LAWS within the Japanese National Diet. Therefore, it is fair to argue that the political stances of Japanese legislators, as well as Japan's antiwar pacifism, are consistent with the premise of classical liberalism. Second, Japan's participation in and support for the CCW conferences and GGE meetings are congruous with the premise of neoliberalism, i.e. international cooperation in creating international regimes. Although the Japanese government has been cautious of outlawing the creation of LAWS by creating a legally binding treaty at this stage, the government has promised not to develop LAWS and argued that LAWS should not be created under the terms of international law.

Third, from a classical realist perspective, the Japanese government has sought to protect its national interests in relation to the regulation of LAWS. The government has indicated concerns that if the legal regulations on AI weapons apply to the civil use of AI technology, it might jeopardize Japan's international competitiveness in the fields of robotics and AI. Moreover, it is obvious that the Japanese government would like to facilitate the use of AI technology for the defensive purpose of lessening the physical and psychological burdens of the SDF. Fourth, a neorealist viewpoint provides an assertive explanation on why the United States, Russia, China, and other countries have made efforts to apply AI technology to their military strategies in an anarchic world. It is logical that the U.S. policy on LAWS could influence Japan's defense and strategic policy, as well as its AI-equipped defense capabilities.

Finally, it is evident that legal prohibition or regulation in the framework of the CCW is not the only pathway to illegalizing LAWS. The creation of a legally binding treaty banning the development of LAWS should not be ruled out as an ultimate goal, although such a treaty would not be supported by the United States, Russia, or other countries that are interested in the enhancement of their "semiautonomous" weapons systems. Still, it is possible for the Japanese government and other UN member states to facilitate international discussions and agree on a "political declaration" to regulate LAWS as a first step. Such a declaration can be upgraded into an international agreement which provides a legally binding framework. It may be difficult for the international community to completely regulate or illegalize LAWS once such weapons systems are created and deployed. The development of LAWS could transform the nature of future military conflicts in an inhumane and catastrophic manner. Therefore, Japan, as a former militarist state that invaded countries of the Asia Pacific region, as a pacifist state with a Peace Constitution, as the sole state to have suffered from nuclear bombings, and as a leader in technology, is responsible for spearheading further international discussions on the legal prohibition or regulation of LAWS. 


\section{References}

Acheson, Ray. 2016. "Editorial: As the World Burns." CCW Report 4 (1): 1-2.

Advisory Council on International Affairs. 2015. "Autonomous Weapon Systems: The Need for Meaningful Human Control.” No. 97 AIV/No. 26 CAVV. https://aiv-advice.nl/ download/606cb3b1-a800-4f8a-936f-af61ac991dd0.pdf (accessed April 5, 2019).

Akimoto, Daisuke. 2018. "The Nuclear Weapons Prohibition Treaty and the Paradox of Japan's Nuclear Identity.” Journal of International and Global Studies 17 (2): 58-75.

Alston, Philip. 2010. "Interim Report of the Special Rapporteur on Extrajudicial, Summary or Arbitrary Executions.” A/65/321, United Nations General Assembly, August 23. https://documents-dds-ny.un.org/doc/UNDOC/GEN/N10/492/39/PDF/N1049239. pdf (accessed January 5, 2019).

Anderson, Kenneth, and Matthew Waxman. 2013. "Law and Ethics for Autonomous Weapon Systems: Why a Ban Won't Work and the Laws of War Can." Stanford University, The Hoover Institution, Jean Perkins Task Force on National Security and Law Essay Series. https://papers.ssrn.com/sol3/papers.cfm?abstract_id=2250126 (accessed September 14, 2019).

Anderson, Kenneth, Daniel Reiser, and Matthew Waxman. 2014. "Adapting the Law of Armed Conflict to Autonomous Weapon Systems." International Law Studies 90: 386411.

Asahi Shimbun. 2019. "Japan to Seek Global Rules on Autonomous 'Killer Robots." March 14. http://www.asahi.com/ajw/articles/AJ201903140039.html (accessed March 29, 2019).

Berger, Thomas U. 1993. “From Sword to Chrysanthemum: Japan's Culture of Antimilitarism." International Security 17 (4): 119-50.

Berger, Thomas U. 1998. Cultures of Antimilitarism: National Security in Germany and Japan. Baltimore: Johns Hopkins University Press.

Bode, Ingvild, and Hendrik Huelss. 2018. "Autonomous Weapons Systems and Changing Norms in International Relations." Review of International Studies 44 (3): 393-413.

Campaign to Stop Killer Robots. 2013. "Report of NGO Conference on the Campaign to Stop Killer Robots.” April 22. http://stopkillerrobots.org/wp-content/uploads/2013/03/ KRC_ReportNGOconf_22Apr2013FNL.pdf (accessed January 13, 2019).

Carter, William A., Emma Kinnucan, and Josh Elliot. 2018. A National Machine Intelligence Strategy for the United States. Washington, DC: Center for Strategic \& International Studies (CSIS).

Crootof, Rebecca. 2015. “The Killer Robots Are Here: Legal and Policy Implications.” Cardozo Law Review 36: 1837-1915.

Delegation of Japan to the Conference on Disarmament. 2014a. "Statement by H.E. Ambassador Toshio Sano Permanent Representative of Japan to the Conference on Disarmament, Experts Meeting of Lethal Autonomous Weapons Systems to the Convention on Prohibitions or Restrictions on the Use of Certain Conventional Weapons Which May Be Deemed to Be Excessively Injurious or to Have Indiscriminate Effects." May 13. https://www.disarm.emb-japan.go.jp/Statements/ 140513\%20CCW\%20LAWS.htm (accessed January 6, 2019).

Delegation of Japan to the Conference on Disarmament. 2014b. "Meeting of the High Contracting Parties to the Convention on Prohibition or Restriction on the Use of 
Certain Conventional Weapons Which May Be Deemed to Be Excessively Injurious or to Have Indiscriminate Effects (CCW)." November 13. https://www.disarm.embjapan.go.jp/Statements/141113_\%20CCW\%20Japan\%20HCP.pdf (accessed January 6, 2019).

Delegation of Japan to the Conference on Disarmament. 2015. "Meeting of the High Contracting Parties to Convention on Prohibition or Restriction on the Use of Certain Conventional Weapons Which May Be Deemed to Be Excessively Injurious or to Have Indiscriminate Effects (CCW).” November 12. https://www.disarm.emb-japan. go.jp/Statements/151112_CCW.htm (accessed January 6, 2019).

Delegation of Japan to the Conference on Disarmament. 2019. "CCW (Convention on Certain Conventional Weapons).” https://www.disarm.emb-japan.go.jp/CCW_info_ jese.html (accessed January 6, 2019).

Di Nucci, Ezio, and Filippo Santoni de Sio, eds. 2016. Drones and Responsibility: Legal, Philosophical and Socio-Technical Perspectives on Remotely Controlled Weapons. London: Routledge.

Evans, Hayley, and Natalie Salmanowitz. 2019. "Lethal Autonomous Weapons Systems: Recent Developments." Lawfare, March 7. https://www.lawfareblog.com/lethalautonomous-weapons-systems-recent-developments (accessed April 4, 2019).

Fang, Lee. 2018. "Google Is Quietly Providing AI Technology for Drone Strike Targeting Project." The Intercept, March 7. https://theintercept.com/2018/03/06/google-isquietly-providing-ai-technology-for-drone-strike-targeting-project (accessed January 9, 2019).

Guardian. 2017. "Elon Musk Leads 116 Experts Calling for Outright Ban of Killer Robots.” August 20. https://www.theguardian.com/technology/2017/aug/20/elon-musk-killerrobots-experts-outright-ban-lethal-autonomous-weapons-war (accessed December 29, 2018).

Heyns, Christof. 2013. "Report of the Special Rapporteur on Extrajudicial, Summary or Arbitrary Executions.” A/HRC/23/47, United Nations General Assembly, April 9. https://documents-dds-ny.un.org/doc/UNDOC/GEN/G13/127/76/PDF/G1312776. pdf (accessed January 5, 2019).

Hook, Glenn D. 1996. Militarization and Demilitarization in Contemporary Japan. London: Routledge.

Human Rights Watch. 2012. “Ban 'Killer Robots' Before It’s Too Late: Fully Autonomous Weapons Would Increase Danger to Civilians.” November 19. https://www.hrw.org/ news/2012/11/19/ban-killer-robots-its-too-late (accessed December 29, 2018).

Human Rights Watch and International Human Rights Clinic Human Rights Program at Harvard Law School. 2012. "Losing Humanity: The Case against Killer Robots." https://www.hrw.org/sites/default/files/reports/arms1112ForUpload_0_0.pdf (accessed December 29, 2018).

Iwamoto, Seigo. 2018. "Robot Heiki to Kokusai Ho (Robot Weapons and International Law)." In Robot/AI to Ho (The Laws of Robots and Artificial Intelligence), eds. Masao Yanaga and Joji Shishido. Tokyo: Yuhikaku, 285-309.

Japan Times. 2019. “Japan's Komeito Political Party Seeks International Regulations on Robotic Weapons.” March 11. https://www.japantimes.co.jp/news/2019/03/11/ national/politics-diplomacy/japans-komeito-political-party-seeks-internationalregulations-robotic-weapons/\#.XJ62O2PV5Ms (accessed March 11, 2019). 
Japan Today. 2014. "Killer Robots: Why We Should Ban Autonomous Weapons Systems." December 2. https://japantoday.com/category/features/opinions/killer-robots-whywe-should-ban-autonomous-weapons-systems (accessed March 30, 2019).

Jha, U. C. 2016. Killer Robots: Lethal Autonomous Weapon Systems Legal, Ethical and Moral Challenges. New Delhi: Vij Books India Pvt Ltd.

Katzenstein, Peter J. 2008. Rethinking Japanese Security: Internal and External Dimensions. New York: Routledge.

Kegley, Charles W., and Shannon L. Blanton. 2011. World Politics: Trend and Transformation. Boston: Wadsworth.

Kilbride, Jack. 2018. "Killer Robots: Chinese University Recruits Talented 'Patriotic' Teens to Help Develop AI Weapons.” ABC News, November 9. https://www.abc.net.au/news/ 2018-11-09/china-recruits-talented-teens-to-help-develop-ai-weapons/10477098 (accessed January 9, 2019).

Kowalska, Paulina. 2018. “Outlawing the Terminators." Shingetsu News Agency. August 28. http://shingetsunewsagency.com/2018/08/28/outlawing-the-terminators (accessed April 7, 2019).

Krishnan, Armin. 2009. Killer Robots: Legality and Ethicality of Autonomous Weapons. London: Routledge.

Kurzweil, Ray. 2005. The Singularity is Near: When Humans Transcend Biology. New York: Penguin Books.

Leveringhaus, Alex. 2016. Ethics and Autonomous Weapons. London: Palgrave Macmillan.

Leys, Nathan. 2018. "Autonomous Weapons Systems and International Crises." Strategic Studies Quarterly 12 (1): 48-73.

MOFA (Ministry of Foreign Affairs, Japan). 2015. "Statement by Toshio Sano Ambassador of Japan to the Conference on Disarmament at the First Committee of the 70th Session of the General Assembly." October 26. https://www.mofa.go.jp/files/000107218. pdf (accessed January 6, 2019).

MOFA (Ministry of Foreign Affairs, Japan). 2017. “The Convention on Prohibition or Restriction on the Use of Certain Conventional Weapons Which May Be Deemed to Be Excessively Injurious or to Have Indiscriminate Effects." November 27. https:// www.mofa.go.jp/mofaj/dns/ca/page25_001111.html (accessed January 6, 2019).

MOFA (Ministry of Foreign Affairs, Japan). 2018a. Diplomatic Bluebook 2018. Tokyo: Ministry of Foreign Affairs, Japan.

MOFA (Ministry of Foreign Affairs, Japan). 2018b. "The GGE Meeting on LAWS, the CCW.” April 16. https://www.mofa.go.jp/mofaj/press/release/press4_005920.html (accessed January 7, 2019).

MOFA (Ministry of Foreign Affairs, Japan). 2018c. “The GGE Meeting on LAWS, the CCW.' September 3. https://www.mofa.go.jp/mofaj/press/release/press4_006392.html (accessed January 7, 2019).

MOFA (Ministry of Foreign Affairs, Japan). 2018d. “The Convention on Prohibition or Restriction on the Use of Certain Conventional Weapons Which May Be Deemed to Be Excessively Injurious or to Have Indiscriminate Effects." November 26. https:// www.mofa.go.jp/mofaj/dns/ca/page25_001727.html (accessed January 7, 2019).

MOFA (Ministry of Foreign Affairs, Japan). 2019. "Possible Outcome of 2019 GGE and Future Actions of International Community on LAWS.” March 22. https://www.mofa. go.jp/mofaj/files/000459707.pdf (accessed March 22, 2019). 
Morgenthau, Hans J. 2006. Politics Among Nations: The Struggle for Power and Peace. Boston: McGraw-Hill Higher Education.

Müller, Vincent C. 2016. "Autonomous Killer Robots are Probably Good News." In Drones and Responsibility: Legal, Philosophical and Socio-Technical Perspectives on Remotely Controlled Weapons, eds. E. Di Nucci and Filippo Santoni de Sio. London: Routledge, 67-81.

NDL (National Diet Library). 1946. “The Constitution of Japan.” https://www.ndl.go.jp/ constitution/e/etc/c01.html (accessed March 26, 2019).

NDL (National Diet Library). 2015. "Proceedings of the 189th Diet Session, the Committee on Foreign Affairs and Defense, the House of Councillors." April 14. http://kokkai. ndl.go.jp/SENTAKU/sangiin/189/0059/18904140059008a.html (accessed December 30, 2018).

NDL (National Diet Library). 2017a. "Proceedings of the 195th Diet Session, the Committee on Education, Culture, Sports, Science and Technology, the House of Representatives." December 1. http://kokkai.ndl.go.jp/SENTAKU/syugiin/195/0096/19512010096003a. html (accessed April 8, 2019).

NDL (National Diet Library). 2017b. "Proceedings of the 195th Diet Session, the Committee on Foreign Affairs and Defense, the House of Councillors." December 5. http:// kokkai.ndl.go.jp/SENTAKU/sangiin/195/0059/19512050059002a.html (accessed December 30, 2018).

NDL (National Diet Library). 2018a. "Proceedings of the 196th Diet Session, the Budget Committee, the House of Representatives.” February 14. http://kokkai.ndl.go.jp/ SENTAKU/syugiin/196/0018/19602140018011a.html (accessed December 31, 2018).

NDL (National Diet Library). 2018b. "Proceedings of the 196th Diet Session, the Committee on Foreign Affairs, the House of Representatives.” March 9. http://kokkai.ndl.go.jp/ SENTAKU/syugiin/196/0005/19603090005002a.html (accessed December 31, 2018).

NDL (National Diet Library). 2018c. "Proceedings of the 196th Diet Session, the Committee on Foreign Affairs, the House of Representatives." April 18. http://kokkai.ndl.go.jp/ SENTAKU/syugiin/196/0005/19604180005009a.html (accessed December 31, 2018).

NDL (National Diet Library). 2018d. "Proceedings of the 197th Diet Session, the Committee on Foreign Affairs, the House of Representatives.” November 14. http://kokkai.ndl. go.jp/SENTAKU/syugiin/197/0005/19711140005002a.html (accessed December 31, 2018).

NDL (National Diet Library). 2019. "Proceedings of the 198th Diet Session, the Committee on Audit, the House of Councillors.” April 4. http://kokkai.ndl.go.jp/SENTAKU/sangi in/198/0015/19804040015002a.html (accessed May 24, 2019).

NHK (Nippon Hoso Kyokai). 2018a. "AI Heiki ni Korosareru? Jinko Chino ga Senjo o Kaeru” [Killed by AI Weapons? AI Will Change Battlefields]. May 10. https://www3. nhk.or.jp/news/web_tokushu/2018_0510.html (accessed January 7, 2019).

NHK (Nippon Hoso Kyokai). 2018b. “'AI Heiki' Saishin Doko” [The Trend of 'AI Weapons']. September 21. https://www.nhk.or.jp/ohayou/digest/2018/09/0921.html (accessed January 7, 2019).

NIDS (National Institute for Defense Studies). 2017. East Asian Strategic Review 2017. Tokyo: National Institute for Defense Studies.

O'Hanlon, Michael. 2007. “A Defense Posture for Multilateral Security." In Japan in International Politics: The Foreign Policies of an Adaptive State, eds. Thomas U. Berger, 
Mike M. Mochizuki, and Jitsuo Tsuchiyama. London: Lynne Rienner Publishers.

Oros, Andrew L. 2008. Normalizing Japan: Politics, Identity, and the Evolution of Security Practice. Stanford, CA: Stanford University Press.

Oros, Andrew L. 2017. Japan's Security Renaissance: New Policies and Politics for the TwentyFirst Century. New York: Columbia University Press.

Perrigo, Billy. 2018. "A Global Arms Race for Killer Robots Is Transforming the Battlefield." Time. April 9. https://time.com/5230567/killer-robots (accessed January 7, 2019).

Prakash, Abishur. 2017. “Japanese Military Drones, Robotics Develop in Response to U.S.-China Pivot.” Robotics Business Review. February 21. https://www. roboticsbusinessreview.com/unmanned/japanese-military-drones-robotics-developresponse-u-s-china-pivot (accessed April 7, 2019).

Pyle, Kenneth B. 2007. Japan Rising: The Resurgence of Japanese Power and Purpose. New York: A Century Foundation Book, PublicAffairs.

Reuters. 2018. "Seifu, AI Robo Heiki Kiseini Shincho" [The Government Is Cautious about the Regulation of AI Robot Weapons]. July 10. https://jp.reuters.com/article/ idJP2018071001002309 (accessed January 7, 2019).

Robillard, Michael. 2018. “The Killer Robots Are 'US.” New York Times, January 29. https:// www.nytimes.com/2018/01/29/opinion/killer-robots-weapons.html (accessed March 28, 2019).

Sankei Shimbun. 2018. "AI no Gunji Riyo o Tabushi surunakare” [Don’t Regard Military Use of AI as a Taboo]. December 28. https://www.sankei.com/politics/news/181228/ plt1812280001-n1.html (accessed January 4, 2019).

Sato, Heigo. 2017. "LAWS (Lethal Autonomous Weapon System) at CCW." Journal of World Affairs 65 (3): 56-66.

Schmitt, Michael N., and Jeffrey S. Thurnher. 2013. "'Out of the Loop': Autonomous Weapon Systems and the Law of Armed Conflict." Harvard National Security Journal 4: 231-81.

Sharkey, Noel. 2007. "Robot Wars Are a Reality." Guardian, August 18. https://www. theguardian.com/commentisfree/2007/aug/18/comment.military (accessed January 5, 2019).

Singer, Peter W. 2009. Wired for War: The Robotics Revolution and Conflict in the 21st Century. New York: Penguin Books.

United Nations. 1976. “International Covenant on Civil and Political Rights.” https:// treaties.un.org/doc/publication/unts/volume\%20999/volume-999-i-14668-english. pdf (accessed April 4, 2019).

United Nations. 1979. "Protocol Additional to the Geneva Conventions of 12 August 1949, and Relating to the Protection of Victims of International Armed Conflicts (Protocol 1)." June 8, 1977. https://treaties.un.org/doc/publication/unts/volume\%201125/ volume-1125-i-17512-english.pdf (accessed April 9, 2019).

UNODA (United Nations Office for Disarmament Affairs). 2017. UNODA Occasional Papers 30. New York: United Nations.

UNOG (United Nations Office at Geneva). 2015. “The Second Informal Meeting of Experts on Lethal Autonomous Weapons Systems to the Convention on Prohibition or Restriction on the Use of Certain Conventional Weapons Which May Be Deemed to Be Excessively Injurious or to Have Indiscriminate Effects." April 13. https://www. unog.ch/80256EDD006B8954/(httpAssets)/7C284472DDBBA998C1257E26005EA5 
DC/\$file/2015_LAWS_MX_Japan.pdf (accessed January 6, 2019).

UNOG (United Nations Office at Geneva). 2016. "Japan's Views on Issues Relating to LAWS.” April 11. https://www.unog.ch/80256EDD006B8954/(httpAssets)/4E8371E AD5E34263C1257F8C00289B5E/\$file/2016_LAWS+MX_CountryPaper+Japan.pdf (accessed January 6, 2019).

UNOG (United Nations Office at Geneva). 2019a. "Convention on Prohibitions or Restrictions on the Use of Certain Conventional Weapons Which May Be Deemed to Be Excessively Injurious or to Have Indiscriminate Effects." https://www.unog.ch/ 80256EDD006B8954/(httpAssets)/51609D467F95DD5EC12571DE00602AED/ \$file/CONVENTION.pdf (accessed January 6, 2019).

UNOG (United Nations Office at Geneva). 2019b. "Meetings of the GGE - CCW." https:// www.unog.ch/80256EE600585943/(httpPages)/49166481C076C45AC12571C0003A5 1 C0?OpenDocument (accessed March 2, 2019).

UNOG (United Nations Office at Geneva). 2019c. "The Convention on Certain Conventional Weapons.” https://www.unog.ch/80256EE600585943/\%28httpPages\%2 9/4F0DEF093B4860B4C1257180004B1B30?OpenDocument (accessed April 4, 2019).

USDOD (United States Department of Defense). 2012. "Directive 3000.09, Autonomy in Weapon Systems.” November 21. https://www.hsdl.org/?view\&did=726163 (accessed January 4, 2019).

White House. 2017. National Security Strategy of the United States of America. December. Washington, DC: The White House.

Zakrzewski, Cat. 2015. "Musk, Hawking Warn of Artificial Intelligence Weapons." Wall Street Journal, July 27. https://blogs.wsj.com/digits/2015/07/27/musk-hawking-warnof-artificial-intelligence-weapons/ (accessed January 13, 2019).

Daisuke Akimoto is Official Secretary to State Minister of Finance in the House of Representatives, Japan. He is a member of the Japan Association of Disarmament Studies, and former Assistant Professor at the Soka University Peace Research Institute. He obtained a PhD in Asian Studies and International Relations from the University of Western Sydney and an MA in Peace and Conflict Studies from the University of Sydney. His recent publications include The Abe Doctrine: Japan's Proactive Pacifism and Security Strategy (Palgrave Macmillan, 2018). Email: daisuke.akimoto. academic@gmail.com. 